\title{
Nitrate/L-arginine Therapy and Nitric Oxide Levels in the Stomach and Liver of Rats
}

\author{
Fatemeh Mehrazin, ${ }^{1}$ Asghar Ghasemi, ${ }^{2, *}$ and Saleh Zahediasl $^{2}$ \\ ${ }^{1}$ Department of Biology, Damghan Branch, Islamic Azad University, Damghan, IR Iran \\ ${ }^{2}$ Endocrine Physiology Research Center, Research Institute for Endocrine Sciences, Shahid Beheshti University of Medical Sciences, Tehran, IR Iran \\ *Corresponding author: Asghar Ghasemi, Endocrine Physiology Research Center, Research Institute for Endocrine Sciences, Shahid Beheshti University of Medical Sciences, Tehran, \\ IR Iran. E-mail:ghasemi@endocrine.ac.ir
}

Received: February 1, 2014; Accepted: May 29, 2014

\begin{abstract}
Background: The L-arginine/nitric oxide(NO) pathway is a major defensive system in gastric mucosa. Nitrate can restore NO homeostasis when enzymatic NO production becomes dysfunctional.

Objectives: The aim of this study was to investigate the effects of nitrate/L-arginine administration on NO levels in the stomach and liver of rats.

Materials and Methods: In this interventional study, adult male Wistar rats were divided into 3 groups of control, nitrate and L-arginine $(\mathrm{n}=8)$. Rats in the nitrate and L-arginine groups were administered sodium nitrate $(500 \mathrm{mg} / \mathrm{L})$ or L-arginine $(2 \%)$ for one week in drinking water while those in control group consumed tap water. At the end, serum, stomach and liver NO metabolite $\left(\mathrm{NO}_{\mathrm{x}}\right)$ concentrations were measured by the Griess method.

Results: Median (interquartile range) serum $\mathrm{NO}_{\mathrm{x}}$ concentrations in the control group $[28.2(19.6-37.8) \mu \mathrm{mol} / \mathrm{L}]$ were significantly $(\mathrm{P}<0.05)$ different to those of the nitrate $[152.4(111.4-180.2) \mu \mathrm{mol} / \mathrm{L}]$ and L-arginine $[14.5(11.2-21.5) \mu \mathrm{mol} / \mathrm{L}]$ groups. Nitrate administration increased and L-arginine administration decreased stomach and liver NOx levels respectively. A positive correlation was observed between serum concentrations and stomach $(\mathrm{r}=0.847, \mathrm{P}<0.001)$ and $\operatorname{liver}(\mathrm{r}=0.650, \mathrm{P}=0.006) \mathrm{NO}_{\mathrm{x}}$ levels.

Conclusions: Nitrate and L-arginine administration had opposite effects on $\mathrm{NO}_{\mathrm{x}}$ levels in stomach and liver of normal rats. Increase in stomach $\mathrm{NO}_{\mathrm{x}}$ following nitrate administration may be due to gastric nitrate absorption, while the decrease in tissue $\mathrm{NO}_{\mathrm{x}}$ following L-arginine administration may be due to increase in arginase activity. These findings may be important considering current data on the protective roles of dietary nitrate/nitrite.
\end{abstract}

Keywords: L-arginine; Nitrate; Nitric oxide metabolites; Rat

\section{Background}

The L-arginine/nitric oxide (NO) pathway is a major defensive system in gastric mucosa because NO increases mucus generation and thickness and maintains adequate mucosal blood flow $[1,2]$. Reduced NO synthase (NOS) activity predispose the elderly to nonsteroidal antiinflammatory drug gastropathy [3]. It has been reported that using nitroglycerin, a drug that generates NO, is independently associated with a decreased risk of upper gasterointestinal bleeding, which is a result of both increase in blood flow of gastric mucosa and the inhibition of adherence of leukocyte to the endothelium [4].

NO is produced enzymatically from L-arginine by NOS and non-enzymatically from reduction of nitrite [5]. At least, three isoforms of NOS has been identified, i.e. endothelial NOS (eNOS), neural NOS (nNOS), and inducible NOS (iNOS) [5]. The existence of mitochondrial NOS (mtNOS) was reported in 1997 by Ghafourifar and Richter
[6]. NOS-independent NO generation was first described in the stomach [1]; furthermore neural NOS have been found in $50 \%$ of enteric nervous system neurons and in parietal cells [7]. Non-enzymatic NO production from dietary nitrate/nitrite could be a potential blood and tissue reservoir of NO [8].

Oral ingestion of inorganic nitrate generates NO in gastric lumen [9]; in addition, enterosalivary circulation of ingested nitrate provides continuous production of NO in the gastric lumen [9]. Ingested nitrate is converted into nitrite in saliva, which, when swallowed, provides a protective mechanism against ingested pathogens by increasing bactericidal activity of gastric juice and could also act as a reservoir of NO [10]. The storage form of NO in tissues is limited [11] and nitrate, as a cytoprotective element in the diet [8], can restore NO homeostasis when NO production from NOS become dysfunc-

Copyright (C) 2015, Zahedan University of Medical Sciences. This is an open-access article distributed under the terms of the Creative Commons Attribution-NonCommercial 4.0 International License (http://creativecommons.org/licenses/by-nc/4.0/) which permits copy and redistribute the material just in noncommercial usages, provided the original work is properly cited. 
tional [10]. L-arginine is a conditionally essential amino acid and it has been reported that L-arginine as a dietary supplement, could increase NO production $[12,13]$. Despite low L-arginine doses being given as a food-additive for many years [14], some authors believe that considering the highly complex metabolism of L-arginine, exogenous arginine supplementation should be used with great caution or avoided [15].

NO levels in circulation may reflect changes in NO production by tissues [16]; however, it has not been completely clarified whether $\mathrm{NO}_{\mathrm{x}}$ status in tissues, is reflected in the plasma [17].

\section{Objectives}

Considering therapeutic approaches using nitrate/nitrite and L-arginine, the aim of this study was to determine the effect of nitrate and L-arginine administrations, as possible mechanisms for increased $\mathrm{NO}$ availability in tissues, on the serum, stomach, and liver concentrations of nitric oxide metabolites (nitrite+nitrate $=\mathrm{NO}_{\mathrm{x}}$ ) in rats

\section{Materials and Methods}

\subsection{Animals and Study Protocol}

In this interventional study, a total of 24 male Wistar rats (220 - $250 \mathrm{~g}$ and 14 weeks old) were maintained in standard conditions (temperature $22 \pm 3^{\circ} \mathrm{C}$; relative humidity $50 \pm 6 \%$ ) with 12 hour light/dark cycles. All experiments were carried out in accordance with standards approved by the local ethics committee of the Research Institute for Endocrine Sciences, Shahid Beheshti University of Medical Sciences. Animals, divided into 3 groups ( $\mathrm{n}=8$ in each group), the control, nitrate, and L-arginine groups, had free access to standard rat chow (Pars Co., Tehran) and water during the study. Rats in the nitrate and L-arginine groups were administered sodium nitrate $(500 \mathrm{mg} / \mathrm{L}$ ) or L-arginine (2\%) for one week in drinking water while the controls consumed tap water. At the end, after 12 - 14 hour fasting a blood sample was obtained for serum $\mathrm{NO}_{\mathrm{x}}$ measurement and stomach and liver samples for $\mathrm{NO}_{\mathrm{x}}$ measurement were prepared as previously described [18]; in brief, animals were anesthetized with sodium pentobarbital (60 mg/ $\mathrm{kg}$, i.p.) and after thoracotomy, organs were flushed free of blood, using EDTA/N-ethylmaleimide solution (10/2.5 $\mathrm{mmol} / \mathrm{L}$ ) freshly prepared in phosphate buffer saline perfused through the left ventricle for 2 minute while blood drained through the right auricle. Stomach and liver were removed, weighed and homogenized in icecold perfusion solution by a homogenizer (Miccra D-1, Germany) and sonicated with a Microson XL 2000 sonicator (USA) while immersed in an ice-water bath.

\subsection{Serum and Tissue NOx Measurement}

Serum and tissue $\mathrm{NO}_{\mathrm{x}}$ concentrations were measured by the Griess reaction [18]. In brief, serum samples were deproteinized by zinc sulfate $(15 \mathrm{mg} / \mathrm{mL})$, and centrifuged at 10,000 $\mathrm{g}$ for 10 minute; tissue homogenates were first centrifuged at 15,000 g for 20 minute, then zinc sulfate $(15 \mathrm{mg} / \mathrm{mL})$ was added and after one minute shaking, samples were recentrifuged at 15,000 $\mathrm{g}$ for 20 minute. For both serum and tissue samples, a 100 $\mu \mathrm{L}$ of the supernatant was transferred to a microplate well, and $100 \mu \mathrm{L}$ vanadium (III) chloride $(8 \mathrm{mg} / \mathrm{mL}$ ) was added to each well to reduce nitrate to nitrite, as the Griess reaction detects only nitrite. Griess reagents [50 $\mu \mathrm{L}$ sulfanilamide $(2 \%)$ and $50 \mu \mathrm{L}$ N-ethylenediamine dihydrochloride (0.1\%)] were then added and samples were incubated for 30 minute at $37^{\circ} \mathrm{C}$; absorbance was read at $540 \mathrm{~nm}$ using the ELISA reader (Sunrise, Tecan, Austria). $\mathrm{NO}_{\mathrm{x}}$ concentration was determined from the linear standard curve established by $0-150 \mu \mathrm{mol}$ sodium nitrate. Inter- and intra-assay coefficients of variation were $5.2 \%$ and $4.4 \%$ respectively. The sensitivity of the assay was $2.0 \mu \mathrm{mol} / \mathrm{L}$ and its recovery was $93 \pm 1.5 \%$. The protein content of the homogenates was determined by the Bradford method [19] and bovine serum albumin (BSA) was used as a standard; tissue $\mathrm{NO}_{\mathrm{x}}$ levels were expressed as nmol/mg protein.

SPSS-20 was used for statistical analyses. Because of the skewed distribution of $\mathrm{NO}_{\mathrm{x}}$ values, non-parametric statistics were used and data were presented as median (interquartile range). Kruskal-Wallis one-way ANOVA was used to compare the effects of sodium nitrate and L-arginine administration in different groups and Mann-Whitney U test was used for pairwise comparison. Spearman correlation coefficient was calculated between serum and tissue $\mathrm{NO}_{\mathrm{x}}$ levels. Two-sided $\mathrm{P}$ values $<0.05$ were considered statistically significant.

\section{Results}

In the control group, median (interquartile range) stomach $\mathrm{NO}_{\mathrm{x}}$ was $1.02(0.81$ - 1.34) $\mu \mathrm{mol} / \mathrm{L}$; nitrate administration, significantly $(\mathrm{P}<0.001)$ increased 5.16 (4.50 - 5.53) $\mu \mathrm{mol} / \mathrm{L}$ and L-arginine administration significantly $(\mathrm{P}<0.05)$ decreased 0.57 ( 0.17 - 0.87) $\mu \mathrm{mol} / \mathrm{L}$ stomach $\mathrm{NO}_{\mathrm{x}}$ levels (Figure $1 \mathrm{~A}$ ). Liver $\mathrm{NO}_{\mathrm{x}}$ in the control group was $0.52(0.22-0.86) \mu \mathrm{mol} / \mathrm{L}$; nitrate administration, significantly $(\mathrm{P}<0.05)$ increased 1.08 $\left(0.60\right.$ - 1.19) $\mu \mathrm{mol} / \mathrm{L}$ liver $\mathrm{NO}_{\mathrm{x}}$ levels while L-arginine administration decreased it to non-detectable levels (Figure $2 \mathrm{~A}$ ). Median (interquartile range) serum $\mathrm{NO}_{\mathrm{x}}$ concentrations in the control group 28.2 (19.6 - 37.8) $\mu \mathrm{mol} / \mathrm{L}$ differed significantly $(\mathrm{P}<0.05)$ from those of the nitrate $152.4(111.4-180.2) \mu \mathrm{mol} / \mathrm{L}$, and L-arginine 14.5 (11.2 - 21.5) $\mu \mathrm{mol} / \mathrm{L}$ groups.

Spearman correlations between serum and tissue $\mathrm{NO}_{\mathrm{x}}$ are shown in Figures $1 \mathrm{~B}$ and 2B. Positive correlations were observed between serum and the stomach $(\mathrm{r}=0.847, \mathrm{P}<0.001)$ and liver $(\mathrm{r}=0.650, \mathrm{P}=0.006) \mathrm{NO}_{\mathrm{x}}$ levels. 


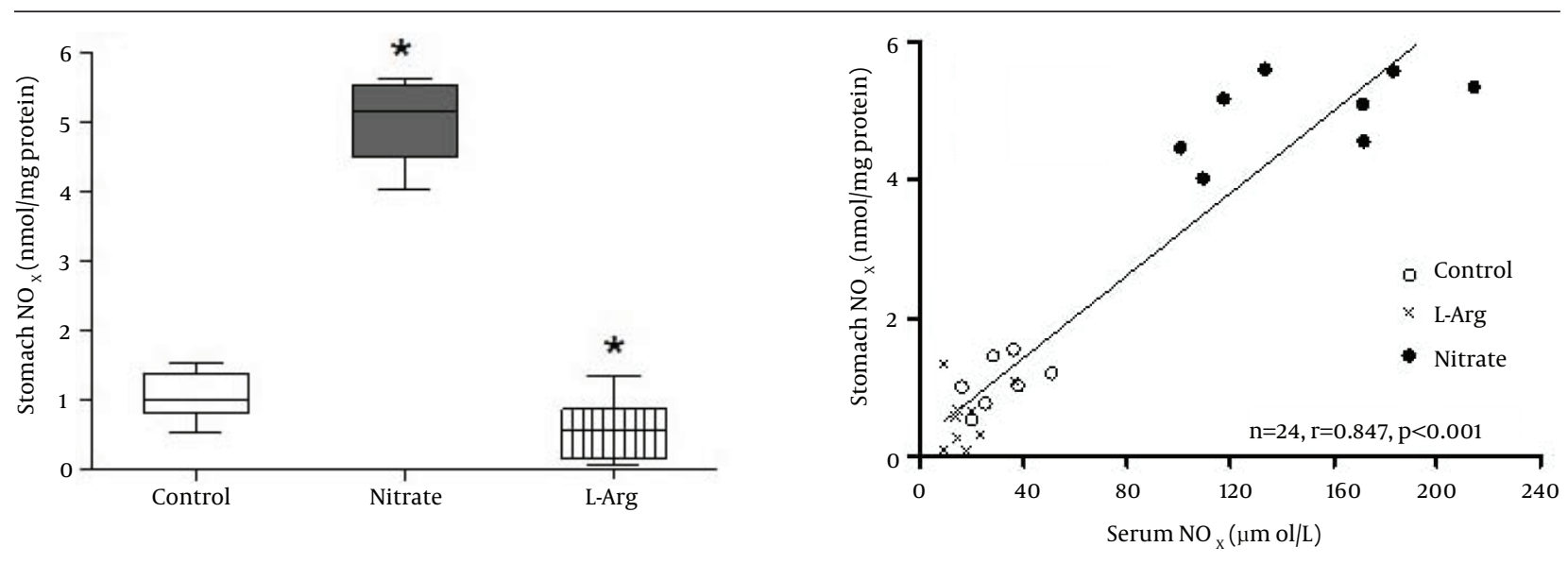

Figure 1. A, Box plots showing the effects of sodium nitrate and L-arginine administration on $\mathrm{NO}_{\mathrm{x}}$ levels of the stomach. Median (interquartile range) stomach $\mathrm{NO}_{\mathrm{X}}$ was $1.02(0.81-1.34) \mu \mathrm{mol} / \mathrm{L}$ in the control group; nitrate administration significantly $(\mathrm{P}<0.001)$ increased $5.16(4.50-5.53) \mu \mathrm{mol} / \mathrm{L}$ and $\mathrm{L}$ arginine administration significantly $(\mathrm{P}<0.05)$ decreased $0.57(0.17-0.87) \mu \mathrm{mol} / \mathrm{L}$ stomach $\mathrm{NO}_{\mathrm{X}}$ levels; $\mathrm{B}$, Correlation between serum and stomach $\mathrm{NO}{ }_{\mathrm{X}}$ content. * Significant difference compared to control group.
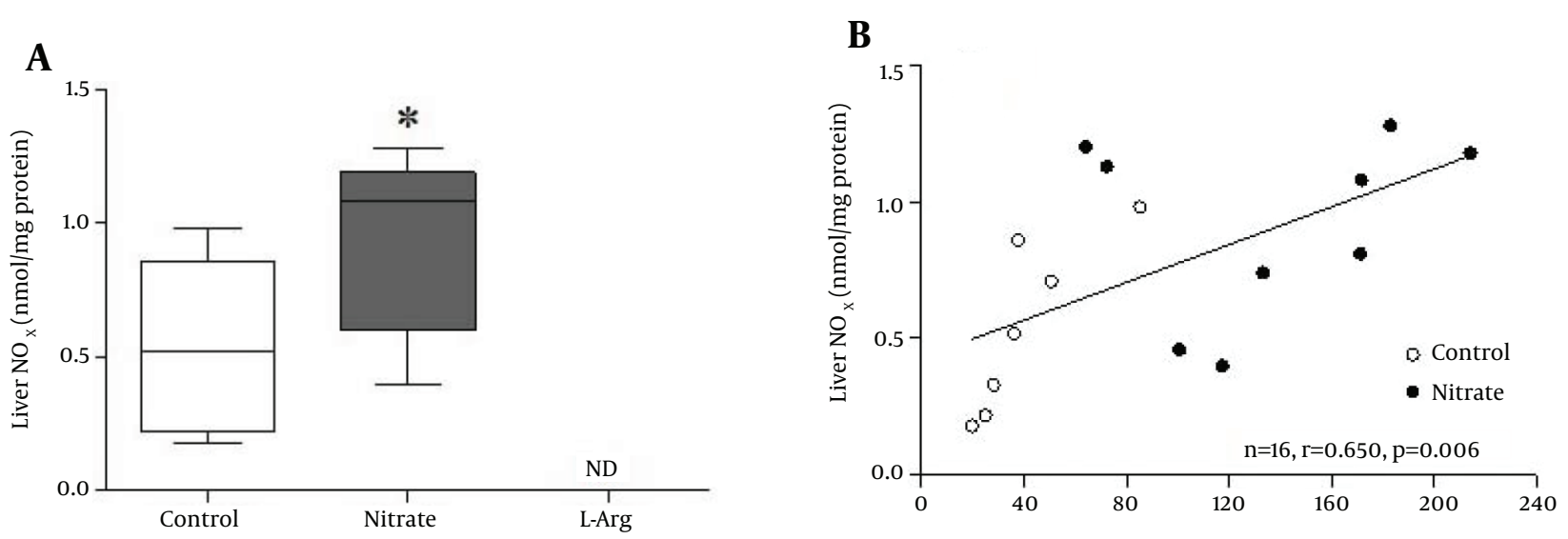

Figure 2. A, Box plots showing the effects of sodium nitrate and L-arginine administration on $\mathrm{NO}_{\mathrm{X}}$ levels of the liver. Liver $\mathrm{NO}_{\mathrm{X}}$ in the control group was $0.52(0.22-0.86) \mu \mathrm{mol} / \mathrm{L}$; nitrate administration significantly $(\mathrm{P}<0.05)$ increased $1.08(0.60-1.19) \mu \mathrm{mol} / \mathrm{L}$ liver $\mathrm{NO}_{\mathrm{X}}$ levels while $\mathrm{L}$-arginine administration decreased it to non-detectable levels; B, Correlation between serum and liver $\mathrm{NO}_{\mathrm{X}}$ content. * Significant difference compared to control group; $\mathrm{ND}$, nondetectable.

\section{Discussion}

The results of this study indicated a 4.1-fold and 1.1-fold increases in stomach and liver $\mathrm{NO}_{\mathrm{x}}$ contents respectively of rat following one week oral nitrate administration, demonstrating the effect of dietary nitrate administration on systemic NO metabolites $[18,20]$ and tissue nitrite [18-21] levels. In line with our results, Jansson et al. [1] have reported 10.7 folds increase in nitrate levels of stomach following one-week administration of sodium nitrate of $1 \mathrm{mmol} / \mathrm{kg}$ in rats, a dose approximately twice that which we used in the current study (500 $\mathrm{mg} / \mathrm{L}$ or $0.6 \mathrm{mmol} / \mathrm{kg}$ ). Raat et al. [8] have reported 1.5-fold and 2.3-fold increases in stomach nitrate content following one-week administration of $300 \mathrm{mg} / \mathrm{L}$ and 1,500 mg/L sodium nitrite respectively. Nitrate is considered as a prodrug of nitrite [22] and similar to our results Duranski et al. [23] have re- ported that nitrite treatment increases liver nitrite levels in mice.

The changes we observed in stomach and liver $\mathrm{NO}_{\mathrm{x}}$ contents following nitrate administration were different; it has been reported that differences in nitrite concentrations between tissues may reflect the degree of NOS activity and the oxidation pathways of NO [24]; however, increased $\mathrm{NO}_{\mathrm{x}}$ content of the stomach following nitrate administration may also be attributed in part to nitrate absorption from the stomach [25].

In the current study, we found relatively high correlations between serum concentrations and gastric and liver $\mathrm{NO}_{\mathrm{x}}$ levels, a finding in line with a previous report that nitrate concentration of the blood is a major determinant of $\mathrm{NO}_{\mathrm{x}}$ levels of the rest of the body [26]. Close 
correlation between plasma and tissue nitrite after nitrite administration has been previously reported [24]. Similar to our results, Raat et al. [8] have reported a direct correlation between plasma and liver nitrite concentrations; some authors have suggested that high correlation between serum and some tissue $\mathrm{NO}_{\mathrm{x}}$ indicates non-specific accumulation of $\mathrm{NO}_{\mathrm{x}}$ in these organs [27] while others suggest that anion transporters aid regulated and tissue-specific transport of nitrite across cell membranes $[24,28]$.

Recent findings suggest that nitrate/nitrite could be considered as potential therapeutic agents [29, 30]. Following oral nitrate intake, large amounts of NO is produced in stomach, amounts greater than that required for vasodilation; the excess amount can contribute to host defense and in gastric physiology [31, 32]. One-week nitrate therapy has prevented gastric injury induced by diclofenac in rats, which may be due to increased intragastric NO formation and stimulation of mucus formation [1]. On the other hand, cancer, in particular stomach cancer, was a concern of nitrate/nitrite consumption [10, 29]. In our study, according to food and water intake measurements, rats received 13 and $51 \mathrm{mg} / \mathrm{kg} /$ day nitrate for one week in the control and nitrate groups respectively. It has been reported that sodium nitrite of $130 \mathrm{mg} / \mathrm{kg}$ in male rats for 2 years is not carcinogen [10]. Although still in doubt, it has been recently reported that old hypothesis of association between (stomach) cancer and ingested nitrate/nitrite is not supported by new data and there is no evidence implicating nitrate/nitrite as an animal or human carcinogen [10].

In the current study, L-arginine administration decreased levels of stomach $\mathrm{NO}_{\mathrm{x}}$ by $44 \%$ and those of liver $\mathrm{NO}_{\mathrm{x}}$ to non-detectable values. In line with our results, Ohta and Nishida [2] have reported that administration of L-arginine could prevent stress-induced increases in the gastric mucosa $\mathrm{NO}_{\mathrm{x}}$ levels in rats. L-arginine increases arginase activity, which could decrease NO production by NOS [18] via reducing substrate availability [33]. In addition, decarboxylation of L-arginine by the arginine decarboxylase produces agmatine [34], which is a competitive inhibitor of the NOS isoenzymes [35] and could inhibit all isoforms of NOS and NO production $[36,37]$. While there are several reports of the protective effect of L-arginine administration against development of gastric mucosal lesion [2], it has recently been reported that L-arginine metabolism could impair antimicrobial NO synthesis in stomach and cause $H$. $p y$ lori induced DNA damage [38]. In addition, it seems that L-arginine does not stimulate NO production in vitro unless during L-arginine deficiency; some of L-arginine actions in vivo, previously attributed to increase NO production, may be due to other mechanisms including increase in insulin secretion [39].

In conclusion, the results of this study indicate that nitrate and L-arginine administration had opposite effects on the $\mathrm{NO}_{\mathrm{x}}$ levels in the stomach and liver of normal rats.
In addition, direct correlations were observed between serum and the tissues $\mathrm{NO}_{\mathrm{x}}$ levels, findings which may be important considering the fast accumulating evidence on the protective roles of dietary nitrate and nitrite.

\section{Acknowledgements}

This work is a part of MSc thesis of Fatemeh Mehrazin and was supported by grant No. 350 from the Research Institute for Endocrine Sciences, Shahid Beheshti University of Medical Sciences. The authors wish to thank Ms. N. Shiva for critical editing for english grammar and syntax of the manuscript.

\section{Authors' Contributions}

Fatemeh Mehrazin and Asghar Ghasemi wrote the article, Fatemeh Mehrazin, Asghar Ghasemi, and Saleh Zahediasl carried out the literature search, Asghar Ghasemi and Fatemeh Mehrazin participated in data collection, Saleh Zahediasl and Asghar Ghasemi participated in the design of the study and in the approval of the final version to be submitted. All authors read and approved the final manuscript.

\section{Funding/Support}

This work was supported by the Research Institute for Endocrine Sciences, Shahid Beheshti University of Medical Sciences.

\section{References}

1. Jansson EA, Petersson J, Reinders C, Sobko T, Bjorne H, Phillipson $\mathrm{M}$, et al. Protection from nonsteroidal anti-inflammatory drug (NSAID)-induced gastric ulcers by dietary nitrate. Free Radic Biol Med. 2007;42(4):510-8.

2. Ohta Y, Nishida K. L-arginine protects against stress-induced gastric mucosal lesions by preserving gastric mucus. Clin Exp Pharmacol Physiol. 2002;29(1-2):32-8.

3. Seo PJ, Kim N, Kim JH, Lee BH, Nam RH, Lee HS, et al. Comparison of Indomethacin, Diclofenac and Aspirin-Induced Gastric Damage according to Age in Rats. Gut Liver. 2012;6(2):210-7.

4. Lanas A, Bajador E, Serrano P, Fuentes J, Carreno S, Guardia J, et al. Nitrovasodilators, low-dose aspirin, other nonsteroidal antiinflammatory drugs, and the risk of upper gastrointestinal bleeding. N Engl J Med. 2000;343(12):834-9.

5. Ghasemi A, Zahediasl S. Preanalytical and analytical considerations for measuring nitric oxide metabolites in serum or plasma using the Griess method. Clin Lab. 2012;58(7-8):615-24.

6. Ghafourifar P, Richter C. Nitric oxide synthase activity in mitochondria. FEBS Lett. 1997;418(3):291-6.

7. Nahravanian H, Amini M. Nitric oxide functions; an emphasis on its diversity in infectious diseases. Iran J Basic Med Sci. 2009;11(4):197-204

8. Raat NJ, Noguchi AC, Liu VB, Raghavachari N, Liu D, Xu X, et al Dietary nitrate and nitrite modulate blood and organ nitrite and the cellular ischemic stress response. Free Radic Biol Med. 2009;47(5):510-7.

9. Pannala AS, Mani AR, Spencer JP, Skinner V, Bruckdorfer KR, Moore KP, et al. The effect of dietary nitrate on salivary, plasma, and urinary nitrate metabolism in humans. Free Radic Biol Med. 2003;34(5):576-84

10. Bryan NS, Alexander DD, Coughlin JR, Milkowski AL, Boffetta P Ingested nitrate and nitrite and stomach cancer risk: an updated review. Food Chem Toxicol. 2012;50(10):3646-65. 
11. Kelm M. Nitric oxide metabolism and breakdown. Biochim Biophys Acta. 1999;1411(2-3):273-89.

12. Evans RW, Fernstrom JD, Thompson J, Morris SJ, Kuller LH. Biochemical responses of healthy subjects during dietary supplementation with L-arginine. J Nutr Biochem. 2004;15(9):534-9.

13. Blum A, Cannon R3, Costello R, Schenke WH, Csako G. Endocrine and lipid effects of oral L-arginine treatment in healthy postmenopausal women. J Lab Clin Med. 2000;135(3):231-7.

14. Hayde M, Vierhapper H, Lubec B, Popow C, Weninger M, Xi Z, et al. Low-dose dietary L-arginine increases plasma interleukin 1 alpha but not interleukin 1 beta in patients with diabetes mellitus. $C y$ tokine. 1994;6(1):79-82.

15. Dioguardi FS. To give or not to give? Lessons from the arginine paradox. J Nutrigenet Nutrigenomics. 2011;4(2):90-8.

16. Zeballos GA, Bernstein RD, Thompson CI, Forfia PR, Seyedi N Shen $\mathrm{W}$, et al. Pharmacodynamics of plasma nitrate/nitrite as an indication of nitric oxide formation in conscious dogs. Circulation. 1995;91(12):2982-8.

17. Bryan NS, Calvert JW, Elrod JW, Gundewar S, Ji SY, Lefer DJ. Dietary nitrite supplementation protects against myocardial ischemiareperfusion injury. Proc Natl Acad Sci U S A. 2007;104(48):19144-9.

18. Ghasemi A, Mehrazin F, Zahediasl S. Effect of nitrate and L-arginine therapy on nitric oxide levels in serum, heart, and aorta of fetal hypothyroid rats. J Physiol Biochem. 2013;69(4):751-9.

19. Bradford MM. A rapid and sensitive method for the quantitation of microgram quantities of protein utilizing the principle of protein-dye binding. Anal Biochem. 1976;72(1-2):248-54.

20. Elrod JW, Calvert JW, Gundewar S, Bryan NS, Lefer DJ. Nitric oxide promotes distant organ protection: evidence for an endocrine role of nitric oxide. Proc Natl Acad Sci U S A. 2008;105(32):11430-5.

21. Bryan NS, Fernandez BO, Bauer SM, Garcia-Saura MF, Milsom $A B$, Rassaf $T$, et al. Nitrite is a signaling molecule and regulator of gene expression in mammalian tissues. Nat Chem Biol. 2005;1(5):290-7.

22. Lundberg JO, Gladwin MT, Ahluwalia A, Benjamin N, Bryan NS Butler A, et al. Nitrate and nitrite in biology, nutrition and therapeutics. Nat Chem Biol. 2009;5(12):865-9.

23. Duranski MR, Greer JJ, Dejam A, Jaganmohan S, Hogg N, Langston $\mathrm{W}$, et al. Cytoprotective effects of nitrite during in vivo ischemiareperfusion of the heart and liver. J Clin Invest. 2005;115(5):123240.

24. Kevil CG, Kolluru GK, Pattillo CB, Giordano T. Inorganic nitrite therapy: historical perspective and future directions. Free Radic Biol Med. 2011;51(3):576-93.

25. Webb AJ, Patel N, Loukogeorgakis S, Okorie M, Aboud Z, Misra S, et al. Acute blood pressure lowering, vasoprotective, and anti- platelet properties of dietary nitrate via bioconversion to nitrite. Hypertension. 2008;51(3):784-90.

26. Wagner DA, Schultz DS, Deen WM, Young VR, Tannenbaum SR. Metabolic fate of an oral dose of $15 \mathrm{~N}$-labeled nitrate in humans: effect of diet supplementation with ascorbic acid. Cancer Res. 1983;43(4):1921-5.

27. Sakemi K, Ohno Y, Tsuda M. [NO2-/NO3- levels in blood and principal organs in rats treated with lipopolysaccharide]. Kokuritsu Iyakuhin Shokuhin Eisei Kenkyusho Hokoku. 1998;(116):101-6.

28. Vitturi DA, Teng X, Toledo JC, Matalon S, Lancaster JJ, Patel RP. Regulation of nitrite transport in red blood cells by hemoglobin oxygen fractional saturation. Am J Physiol Heart Circ Physiol. 2009;296(5):H1398-407.

29. Ghasemi A, Zahediasl S. Potential therapeutic effects of nitrate/ nitrite and type 2 diabetes mellitus. Int J Endocrinol Metab. 2013;11(2):63-4.

30. Weitzberg E, Lundberg JO. Dietary nitrate - a slow train coming.J Physiol. 2011;589(Pt 22):5333-4.

31. McKnight GM, Smith LM, Drummond RS, Duncan CW, Golden M, Benjamin N. Chemical synthesis of nitric oxide in the stomach from dietary nitrate in humans. Gut. 1997;40(2):211-4.

32. Gilchrist M, Winyard PG, Benjamin N. Dietary nitrate--good or bad? Nitric Oxide. 2010;22(2):104-9.

33. Masuda H. Significance of nitric oxide and its modulation mechanisms by endogenous nitric oxide synthase inhibitors and arginase in the micturition disorders and erectile dysfunction. Int J Urol. 2008;15(2):128-34.

34. Loscalzo J. Adverse effects of supplemental L-arginine in atherosclerosis: consequences of methylation stress in a complex catabolism? Arterioscler Thromb Vasc Biol. 2003;23(1):3-5.

35. Wu G, Morris SJ. Arginine metabolism: nitric oxide and beyond. Biochem J.1998;336 ( Pt 1):1-17.

36. Galea E, Regunathan S, Eliopoulos V, Feinstein DL, Reis DJ. Inhibition of mammalian nitric oxide synthases by agmatine, an endogenous polyamine formed by decarboxylation of arginine. Biochem J.1996;316 ( Pt 1):247-9.

37. Castellano MA, Rojas-Diaz D, Martin F, Quintero M, Alonso J, Navarro E, et al. Opposite effects of low and high doses of arginine on glutamate-induced nitric oxide formation in rat substantia nigra. Neurosci Lett. 2001;314(3):127-30.

38. Chaturvedi R, de Sablet T, Coburn LA, Gobert AP, Wilson KT. Arginine and polyamines in Helicobacter pylori-induced immune dysregulation and gastric carcinogenesis. Amino Acids. 2012;42(2-3):627-40.

39. Kurz S, Harrison DG. Insulin and the arginine paradox. J Clin Invest. 1997;99(3):369-70. 